\title{
The Screening Provisions Proposed in Bill C-55 (Rules of the Board, documentation respecting the claim with the adjudicator)
}

Applicable provisions

(3) Section 29, subsection 30(1) and section 113 apply, with such modifications as the circumstances require, with respect to a hearing held pursuant to subsection $46(3)$ as if the hearing were an inquiry.

Determinations

48. (1) Where an inquiry is continued or a hearing is held before an adjudicator and a member of the Refugee Division,

a)the adjudicator shall, in the case of an inquiry, determine whether the claimant should be permitted to come into Canada or to remain therein, as the case may be:

b)the adjudicator and the member shall determine whether the claimant is eligible to have the claim determined by the Refugee Division; and

c)if either the adjudicator or the member or both determine that the claimant is so eligible, they shall determine whether the claimant has a credible basis for the claim.

\section{Burden of Proof}

(2) The burden of proving that a claimant is eligible to have the claim determined by the Refugee Division and that the claimant has a credible basis for the claim rests on the claimant.

\section{Hearing of claimant and Minister}

(3) Where the adjudicator and the member of the Refugee Division are considering the matters referred to in paragraphs (1)(b) and (c), they shall afford the claimant and the Minister a reasonable opportunity to present evidence, cross-examine witnesses and make representations with respect to those matters.

\section{Evidence}

(4) The adjudicator and the member of the Refugee Division may base their decisions with respect to the matters referred to in paragraphs (i)(b) and (c) on evidence adduced at the inquiry or hearing and considered credible or trustworthy in the circumstances of the case.

Assessment criteria

48(1) (1) A person who claims to be a Convention refugee is not eligible to have the claim determined by the Refugee Division if

a)the claimant has been recognized by any country, other than Canada, as a Convention refugee and has been issued a valid and subsisting travel document by that country pursuant to Article 28 of the Convention;

b)the claimant came to Canada from a country that has been prescribed as a safe third country for all persons or for persons of a specified class of persons of which the claimant is a member and would be allowed to return to that country, if re- moved from Canada, or has a right to have the claim determined therein;

c)the claimant has, since coming into Canada, been determined

i) by the Refugee Division, the Federal Court of Appeal or the Supreme Court of Canada not to be a Convention refugee or to have abandoned the claim, or

ii) by an adjudicator and a member of the Refugee Division as not being eligible to have the claim determined by that Division or as not having a credible basis for the claim;

d)the claimant has been finally determined under this Act, or determined under the regulations, to be a Convention refugee; or

e)in the case of a claimant to whom a departure notice has been issued, the claimant has not left Canada or, having left Canada pursuant to the notice, has not been granted lawful permission to be in any other country.

2) Notwithstanding paragraph (1)(a), a person is eligible to have a claim determined by the Refugee Division if, in the opinion of the adjudicator or the member of the Refugee Division considering the claim, the person has a credible basis for a well-founded fear of persecution for reasons of race, religion, nationality, membership in a particular social group or political opinion in the country that recognized the person as a Convention refugee.

Last coming into Canada

(3) A claimant who goes to another country and returns to Canada within ninety days shall not, for the purposes of paragraph (1)(c), be considered as coming into Canada on that retum.

Credibility of basis for claim

(4) In determining whether a claimant has a credible basis for the claim to be a Convention refugee, the adjudicator and the member of the Refugee Division shall consider any evidence adduced at the inquiry or hearing regarding a) the record with respect to human rights of the country that the claimant left, or outside of which the claimant remains, or by reason of fear of persecution; and

b) the disposition under this Act or the regulations of claims to be Convention refugees made by other persons who alleged fear of persecution in that country.

The definition of a refugee according to the United Nations Convention on Refugees which was incorporated into Canada's 1976 Immigration Act.

"Convention refugee" means any person who, by reason of a well-founded fear of persecution for reasons of race, religion, nationality, membership in a particular social group or political opinion

a) is outside the country of his nationality and is unable or, by reason of such fear, is unwilling to avail himself of the protection of that country; or

b) not having a country of nationality, is outside the country of his former habitual residence and is unable or, by reason of such fear, is unwilling to return to that country; ...

\section{Breakdown of the 1988 Immigration Level and Compared with 1987}

Family Class

Convention Refugees and Members of Designated Classes

Humanitarian (Special Measures)

Selected Workers:

Principal Applicants

Spouses \& Dependents

Business Immigrants:

Principal Applicants

Spouses and Dependents

Retirees

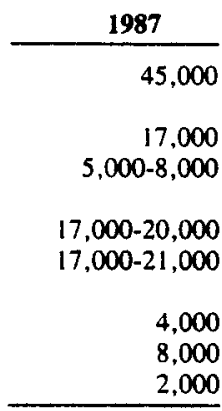

$115,000-125,000$

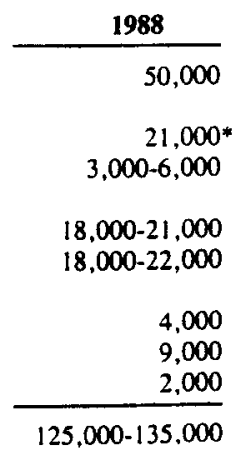

$125,000-135,000$

* Includes 13,000 government-assisted. an estimate of 6,000 privately sponsored from abroad, and an estimate of 2,000 landed in Canada through the refugee Status Advisory Committee.

Government of Canada. Annual Report to Parliament on Future Immigration Levels, Ottawa, December 1987. 